\title{
THE COMBINED USE OF A CENTRAL REGISTRY AND VITAL RECORDS FOR INCIDENCE STUDIES OF CONGENITAL DEFECTS
}

\author{
BY \\ D. H. G. RENWICK \\ Research Officer, Department of Health Services and Hospital Insurance, Health Branch, Division of Vital Statistics, \\ Province of British Columbia, Vancouver, Canada
}

Current interest in the aetiology of congenital defects has increased the need for reliable sources of information about incidence. A central registry with access to a wide variety of reporting sources can play an important part, not only in incidence studies, but in the general epidemiology of these defects.

Such a registry provides a storehouse of readily available and constantly expanding information. By virtue of the diversity of information and the large samples available, important incidence variables, such as sex, race, maternal age, or season of birth, can be taken into account without sacrificing statistical validity. Moreover, the examination of bulk data of this kind often leads to the discerning of epidemiological patterns such as frequency of specific combinations of defects and familial tendencies.

The Registry for Handicapped Children and Adults in British Columbia was established in 1952. At the end of 1965, there were about 30,000 live and dead registered cases, including 20,300 living children or roughly 3 per cent. of the child population of the Province. It is emphasized, however, that this caseload cannot be used as a source of complete information, for the following reasons:

(1) Registration is voluntary.

(2) Until recently minor defects without residual handicap were not registered.

(3) An individual must be alive at the time in order to be registered. (However, those who die subsequently remain on the Registry caseload.)

It is for these reasons that Registry data must be supplemented by information from Provincial Vital Records. Fortunately, a unique feature of the Registry is its close working association with the Division of Vital Statistics and other bodies within the Public Health organization of the Province. This aspect of the Registry is discussed by Mott (1963) in his account of its history and operation.
Previously reported findings based on the conjoint use of Provincial Vital Records and Registry data have dealt mainly with factors influencing the incidence of specific defects. Miller (1964) found that the incidence of cleft lip and palate among the Indians of British Columbia was higher than among Caucasians whereas the pattern was reversed in the case of neural tube anomalies. Renwick, Miller, and Paterson (1964) presented evidence showing that maternal age influenced the incidence of congenital heart disease independently of its association with mongolism. Newcombe (1966) studied familial tendencies in children's diseases by computer linkage and found that almost all the conditions he examined tended to repeat in sibs.

The present communication describes ways of making the Registry data most effective as a source of ascertainment, by combination with different kinds of vital records. It will be shown that the relative importance of the Registry or of any one kind of record depends on the nature of the defect in question. Of particular importance in this respect are:

(a) The relative ease of detection of the defect.

(b) The relative lethality of the defect in the perinatal period.

\section{Augmentation OF INFORMation fRom Live BiRTH} ReCords by Registry Data

The Registry, as a source of incidence data, has two main advantages. The first is access to information relating to defects reported on live birth notices by attending physicians. Through an arrangement with the Division of Vital Statistics, registration of newborn children with defects reported on these records has been in effect since the inception of the Registry. The second advantage is the long period of casefinding inherent in the operation of the Registry, resulting in the subsequent registration of many cases which are "missed" at birth. This advantage is provided through the province-wide reporting of handi- 
capped children to the Registry by provincial and metropolitan health units, voluntary agencies, institutions, hospitals and treatment centres, private physicians, and other sources.

Table I shows the number of live-born children reported on the Physician's Notice of Birth in British Columbia in the years 1952-57 inclusive, as having specified congenital defects, compared with the number of live and dead children originating from the same cohort of births, who were on the Registry at the end of 1964. Also shown are incidence rates per 1,000 live births based on data from these two sources. It can be readily seen that live birth notifications alone are unreliable as a source of incidence data for congenital heart disease, and are inadequate even for some of the gross malformations, such as clubfoot and the cleft lip and palate complex.

TABLE I

CASES WITH SPECIFIED DEFECTS FROM THE 1952-57 COHORT OF 203,642 LIVE BIRTHS IN BRITISH COLUMBIA

\begin{tabular}{|c|c|c|c|c|}
\hline \multirow{2}{*}{ Malformation } & \multicolumn{2}{|c|}{$\begin{array}{l}\text { Reported on } \\
\text { Live Birth } \\
\text { Notifications }\end{array}$} & \multicolumn{2}{|c|}{$\begin{array}{l}\text { On the Live and Dead } \\
\text { Registry Caseload } \\
\text { End of } 1964\end{array}$} \\
\hline & Number & $\begin{array}{c}\text { Rate per } \\
1,000 \text { Live } \\
\text { Births }\end{array}$ & Number & $\begin{array}{l}\text { Rate per } \\
1,000 \text { Live } \\
\text { Births }\end{array}$ \\
\hline Clubfoot .. & 370 & 1.82 & 494 & $2 \cdot 43$ \\
\hline $\begin{array}{c}\text { Cleft palate and/or } \\
\text { Cleft lip }\end{array}$ & 280 & $1 \cdot 37$ & 367 & $1 \cdot 80$ \\
\hline Spina bifida & 186 & 0.91 & 199 & 0.98 \\
\hline Hydrocephalus & 48 & 0.24 & 163 & 0.80 \\
\hline $\begin{array}{c}\text { Congenital heart } \\
\text { disease* }\end{array}$ & 78 & $0 \cdot 38$ & 794 & $3 \cdot 90$ \\
\hline
\end{tabular}

- In this paper this term denotes all cardiovascular defects under the general rubric 754 of the International Classification of Diseases (1955 Revision) as a single entity. A case with more than one of these defects is counted only once.
The important point is that for most defects there is a residue of cases which are not reported to the $?$ Division of Vital Statistics within the 48 hours $\mathbb{D}$ required by law for the submission of a Physician's? Notice of a Live Birth or Stillbirth Notification. This omission may be due to oversight in the case of $-\frac{0}{0}$ overt malformations, or to the essentially occult $\frac{}{0}$ nature of the condition as in the case of congenital $\overline{\bar{p}}$. heart disease, or to post-natal development, as in $\underset{\square}{\square}$ some forms of hydrocephalus.

Since casefinding may extend over a period of many years after birth, the importance of allowing as long. a follow-up period as possible cannot be over- $\vec{\overrightarrow{ }}$ emphasized. This is demonstrated in Table II, which $\stackrel{\omega}{\sigma}$ shows the number of live and dead cases on the $\vec{\otimes}$ Registry at the end of 1964, who were born in the $\mathcal{S}$ biennial periods shown, expressed as rates per $1,000 \mathrm{~N}$ live births in British Columbia in those periods. i There is a general decline with decreasing age. The 9 importance of the schooling period in the casefinding 0 of congenital heart diseases is evident from the Table. There is a high plateau from 1952-57. The live $>$ children born in these years were between the ages of 7 and 12 years in 1964, while, with the partial excep- $\vec{\circ}$ tion of the 1958-59 cohort, the remaining cohorts were still in the pre-school age groups.

The advantage of an extended casefinding period does not apply in the case of an extreme type of mat formation such as anencephaly, which is inevitably recognized at birth and is confined largely to still- $\stackrel{0}{2}$ births. For such malformations, live and stillbirth $\stackrel{\mathbb{Q}}{\circ}$ notifications used in conjunction are a more adequate $\overrightarrow{\vec{O}}$ source of information than the Registry statistics. 3 For most severe defects, Registry data must be supplemented by information from death and stillbirth records, and the degree to which this is necessary is

TABLE II

BRITISH COLUMBIA-BORN REGISTRY CASES WITH SPECIFIED DEFECTS AT THE END OF 1964 BY PERIOD OF BIRTH*

Showing Numbers and Rates per 1,000 Live Births

\begin{tabular}{|c|c|c|c|c|c|c|c|c|c|c|c|}
\hline \multirow[t]{2}{*}{ Biennial Period } & \multirow[t]{2}{*}{$\begin{array}{l}\text { No. of } \\
\text { Live Births }\end{array}$} & \multicolumn{2}{|c|}{ Clubfoot } & \multicolumn{2}{|c|}{$\begin{array}{c}\text { Congenital Heart } \\
\text { Disease }\end{array}$} & \multicolumn{2}{|c|}{ Spina Bifida } & \multicolumn{2}{|c|}{ Hydrocephalus } & \multicolumn{2}{|c|}{$\begin{array}{c}\text { Cleft Palate } \\
\text { and/or } \\
\text { Cleft lip }\end{array}$} \\
\hline & & No. & Rate & No. & Rate & No. & Rate & No. & Rate & No. & Rate \\
\hline $1952-53$ & 61,573 & 159 & $2 \cdot 58$ & 240 & $3 \cdot 90$ & 62 & $1 \cdot 01$ & 59 & 0.96 & 99 & $1 \cdot 61$ \\
\hline 1954-55 & 67,084 & 167 & $2 \cdot 49$ & 261 & $3 \cdot 89$ & 74 & $1 \cdot 10$ & 51 & $0 \cdot 76$ & 137 & $2 \cdot 04$ \\
\hline $1956-57$ & 74,985 & 168 & $2 \cdot 24$ & 293 & $3 \cdot 91$ & 63 & 0.84 & 53 & $0 \cdot 71$ & 131 & $1 \cdot 75$ \\
\hline $1958-59$ & 79,548 & 184 & $2 \cdot 31$ & 236 & $2 \cdot 97$ & 73 & 0.92 & 59 & 0.74 & 129 & $1 \cdot 62$ \\
\hline $1960-61$ & 78,707 & 131 & $1 \cdot 66$ & 161 & $2 \cdot 05$ & 48 & 0.61 & 31 & $0 \cdot 39$ & 124 & $1 \cdot 58$ \\
\hline $1962-63$ & 75,606 & 122 & $1 \cdot 61$ & 147 & $1 \cdot 94$ & 48 & 0.63 & 48 & 0.63 & 113 & $1 \cdot 49$ \\
\hline
\end{tabular}

- Includes all live and dead cases with these defects on the Registry at the end of 1964 excepting cases born in 1964. 
a function of the perinatal mortality factor associated with the defect. This is illustrated in the following three examples of the use of Registry data:

\section{(1) The Registry as a Single Source of Informa- tion-Cleft Lip and Palate Findings}

The Registry by itself is a relatively good source of information for gross malformations with a relatively low stillbirth rate. The incidence rate of a malformation of this type is often expressed as the number of affected live-born children per unit number of live births. The cleft lip and palate complex is a good example.

The estimated incidence rate of cleft lip and/or palate in British Columbia based solely on Registry data is in good agreement with estimates by various authors published recently by Milham (1963) and shown in Table III. It is interesting to note that Milham's own rate of $1 \cdot 80$ per 1,000 births, obtained by combining information from birth and hospital records in Upper New York State, was the same as the rate per 1,000 live births for British Columbia. This rate was similar to rates obtained in Denmark (Fogh-Andersen, 1961) and Finland (Gylling and Soivio, 1962) which Milham (1963) claimed were fortunate from the stand-point of complete reporting.

On the whole, the estimates which were based solely on birth records in Table III are lower than those derived from other sources. The exception to this is the estimate by Henderson (1940) based on birth record information in Hawaii. This, however, is not surprising, since the incidence of this condition is high among the Mongolian peoples, according to Miller (1964) and Neel (1958), and individuals of Japanese and Chinese ancestry constitute a large proportion of the population of Hawaii.

Greene (1963), using data from various sources, found that the combination of cleft palate and cleft lip occurred more frequently than either single component. He also found that cleft lip only and the combination were more common in the male while the reverse was true in the case of cleft palate only. Table IV (overleaf), showing sex-specific incidence patterns of the different types of buccal cavity deformity based on Registry data, lends partial support to these findings. The rates are underestimated for reasons explained in the Table footnote, but the relative differences are for the most part evident.

\section{(2) Registry Data Supplemented by Death Records-Congenital Heart Disease FINDINGS}

The type of malformation which most typically falls into this category is one in which the majority of cases are discovered after the time of birth but, because of the occult nature of the defect and a high

TABLE III

ESTIMATED INCIDENCE RATES OF CLEFT LIP AND/OR CLEFT PALATE

\begin{tabular}{|c|c|c|c|c|c|c|}
\hline $\begin{array}{l}\text { Years } \\
\text { Surveyed }\end{array}$ & Investigator & Date & Source of Cases & $\begin{array}{l}\text { Number } \\
\text { of Cases }\end{array}$ & $\underset{\text { Births* }}{\text { Number of }}$ & $\begin{array}{c}\text { Rate } \\
\text { per } 1,000\end{array}$ \\
\hline $1953-57$ & Fogh-Andersen & 1961 & $\begin{array}{l}\text { Surgical records of Diakonissestiftelsens } \\
\text { Hospital, Copenhagen, Denmark }\end{array}$ & 644 & 393,457 LB & $1 \cdot 64$ \\
\hline $1939-54$ & Gylling and Soivio & 1962 & $\begin{array}{l}\text { Birth records, School of Midwifery, Helsinki, } \\
\text { Finland }\end{array}$ & 80 & 43,461 LB & $1 \cdot 84$ \\
\hline 1940 & Henderson & 1940 & Birth records, Hawaii & 35 & 18,024 LB & 1.94 \\
\hline $1951-55$ & Ivy & 1957 & Birth records, State of Pennsylvania & 1,269 & $1,201,551$ LB & 1.06 \\
\hline 1955 & $\begin{array}{l}\text { Loretz, Westmoreland, } \\
\text { and Richards }\end{array}$ & 1961 & Birth records, State of California & 368 & 313,164 LB & $1 \cdot 18$ \\
\hline $1940-50$ & $\begin{array}{l}\text { McMahon and } \\
\text { McKeown }\end{array}$ & 1953 & $\begin{array}{l}\text { Registers of stillbirths and infant deaths; } \\
\text { hospital records in Birmingham, England }\end{array}$ & 285 & $218,693 \mathrm{~TB}$ & $1 \cdot 30$ \\
\hline $1944-57$ & Pleydell & 1960 & $\begin{array}{l}\text { Register of hospital births, domiciliary births, } \\
\text { infant deaths, and school health department } \\
\text { registers, Northamptonshire, England }\end{array}$ & 101 & 62,224 TB & $1 \cdot 62$ \\
\hline $1945-57$ & Rank and Thompson & 1960 & $\begin{array}{l}\text { Plastic surgery clinic cases, doctors' reports, } \\
\text { death records, hospital records, Tasmania }\end{array}$ & 160 & 96,510 LB & $1 \cdot 66$ \\
\hline 1953 & $\begin{array}{l}\text { Wallace, Hoenig, } \\
\text { and Rich }\end{array}$ & 1956 & Birth records, New York City & 135 & 161,499 LB & 0.84 \\
\hline $1950-60$ & Milham & 1963 & $\begin{array}{l}\text { Birth records and hospital records, } \\
\text { Upper New York State }\end{array}$ & 143 & $79,536 \mathrm{~TB}$ & $1 \cdot 80$ \\
\hline $1952-57$ & Present Study & & $\begin{array}{l}\text { Registry for Handicapped Children and } \\
\text { Adults, British Columbia-1964 Live and } \\
\text { Dead Caseload }\end{array}$ & 367 & 203,642 LB & $1 \cdot 80$ \\
\hline
\end{tabular}

- LB-live births; TB-total births. 
TABLE IV

ESTIMATED SEX-SPECIFIC “INCIDENCE” RATES OF CLEFT LIP AND PALATE, BY TYPE OF DEFECT Based on the 1964 Live and Dead Registry Caseload

\begin{tabular}{|c|c|c|c|c|c|c|}
\hline \multirow[t]{2}{*}{ Type of Defect } & \multicolumn{3}{|c|}{$\begin{array}{l}\text { Number of Cases } \\
\text { Born in B. C. in the Years 1952-63 }\end{array}$} & \multicolumn{3}{|c|}{$\begin{array}{c}\text { Rate per 1,000 Live Births } \\
\text { occurring in B. C., } \\
1952-63\end{array}$} \\
\hline & Male & Female & Total & Male & Female & Total \\
\hline Cleft palate only & 109 & 114 & 223 & 0.49 & 0.53 & 0.51 \\
\hline Cleft lip only. & 112 & 53 & 165 & 0.50 & 0.25 & 0.38 \\
\hline Cleft palate with Cleft lip & 220 & 125 & 345 & 0.98 & 0.58 & 0.79 \\
\hline Total Cleft palate and/or Cleft lip & 441 & 292 & 733 & 1.97 & $1 \cdot 37$ & $1 \cdot 68 *$ \\
\hline Number of Live Births & 223,806 & 213,697 & 437,503 & & & \\
\hline
\end{tabular}

* Slightly lower than the rate of 1.80 for 1952 to 1957 shown in Table III, because of lower rates in the more recent years resulting from a shorter casefinding period. The longer span of time represented in the above Table was necessary in order to obtain sufficiently large numbers $(\bar{D}$ in the sub-categories.

early mortality rate associated with it, many cases are discovered only at necropsy.

Access to death records is therefore important for estimating the incidence of this type of malformation. Congenital heart disease is a good example. Osterud, Menashe, and Martin (1965) in Oregon recently found $2 \frac{1}{2}$ times as many cases with cardiovascular malformations on death certificates as on birth records relating to the same cohort of births. They also found that only 25 per cent. of the number of cases reported on death certificates had previously been reported on birth records. The relative importance of death records when ascertainment is based exclusively on vital records is seen in the Oregon cohort data in Table $\mathrm{V}$, which shows 65 per cent. of all cases to be derived from this source. In British Columbia death records do not play so important a role, since many cases which are missed at birth are registered before they die. However, there is always a residue of cases which remain undetected until death. Cases derived from death records constitute more than 20 per cent. of the total number of British
Columbia cases in Table V. It is evident that the much $\stackrel{\text { N }}{\text { N }}$ higher overall rate per 1,000 live births in the British? Columbia cohort is a result of augmentation by 9 Registry data.

(3) Registry Data Supplemented by Stillbirth RECORDS-SPINA BIFIDA AND HydROCEPHALUS Findings

Another group of defects for which the Regist data must be supplemented is that of malformatio of the central nervous system, such as spina bifidid and hydrocephalus, in which stillbirths constitute large proportion of the total number of affected births.

Gittelsohn and Milham (1962), for example, found that 15 per cent. of the spina bifida cases and almost 60 per cent. of the hydrocephalus cases reported in Upper New York State were stillbirths. Because of the large proportion of stillbirths, incidence rates of malformations such as these are usually expressed as rates per unit number of total live and stillbirths. In order to compare the Upper New York State rates? based on total births with the corresponding rates in

TABLE V

DIFFERENT SOURCES IN CONGENITAL HEART DISEASE CASEFINDING An Illustration of Relative Importance Using British Columbia and Oregon Data

\begin{tabular}{|c|c|c|c|c|c|c|}
\hline \multirow{2}{*}{ Source of Data } & \multicolumn{3}{|c|}{$\begin{array}{l}\text { British Columbia } \\
\text { (1955-57 Cohort of } \\
109,123 \text { live births) }\end{array}$} & \multicolumn{3}{|c|}{$\begin{array}{l}\text { State of Oregon } \\
\text { (1957-61 Cohort of } \\
186,579 \text { live births)* }\end{array}$} \\
\hline & $\begin{array}{l}\text { No. of } \\
\text { C.H.D. } \\
\text { cases }\end{array}$ & Per cent. & $\begin{array}{c}\text { Rate per } \\
1,000 \\
\text { live births }\end{array}$ & $\begin{array}{l}\text { No. of } \\
\text { C.H.D. } \\
\text { cases }\end{array}$ & Per cent. & $\begin{array}{l}\text { Rate per } \\
1,000 \\
\text { live births }\end{array}$ \\
\hline Live birth records & 42 & $7 \cdot 5$ & $0 \cdot 38$ & 144 & $34 \cdot 7$ & 0.77 \\
\hline $\begin{array}{l}\text { British Columbia Registry cases not } \\
\text { reported at birth (as at end of 1964) }\end{array}$ & 392 & $70 \cdot 1$ & $3 \cdot 59$ & - & - & - \\
\hline $\begin{array}{l}\text { Death records (reported for the first time } \\
\text { at death) }\end{array}$ & 125 & $22 \cdot 4$ & $1 \cdot 15$ & $271^{*}$ & $65 \cdot 3$ & $1 \cdot 45$ \\
\hline $\begin{array}{l}\text { Total discovered cases in cohort (to end } \\
\text { of casefinding period) }\end{array}$ & 559 & 100 & $5 \cdot 12$ & 415 & 100 & $2 \cdot 22$ \\
\hline
\end{tabular}


British Columbia, it was necessary to obtain from the Division of Vital Statistics the number of stillbirths with spina bifida and with hydrocephalus born in the period 1952-57 and to add these to the totals shown in Table I. The comparison is shown in Table VIA.

While the overall rates per 1,000 births of $1 \cdot 14$ (British Columbia) and 1.18 (Upper New York State) were similar in the two series in the case of spina bifida, the hydrocephalus rate was 33 per cent. higher in the British Columbia data (1.12 as compared with 0.84). Gittelsohn and Milham (1962), who used birth and death records, noted that hydrocephalus presents a special problem because it may be post-natal in origin. They also suggested that, since many cases developing after birth would have poor viability, they were subject to ascertainment through death records. However, the data indicate that later registration of children missed at birth probably accounted for the higher hydrocephalus rate in British Columbia.

This is brought into sharper focus if live-born and stillborn hydrocephalus rates per 1,000 total births are considered separately. The live-born rate of 0.79 in the British Columbia series was about double the
Upper New York rate of $0 \cdot 35$. On the other hand the stillborn rate in the British Columbia series was only 0.33 as compared with 0.49 in the Upper New York series. This was probably due in part to the fact that the Upper New York data included foetuses of 20 weeks or more gestation, while the limit was 28 weeks in the British Columbia data. (This was so prior to 1963 when foetuses of 20-27 weeks gestation were included for the first time.)

The apparent understatement of live-born hydrocephalus cases in the Upper New York series probably accounted for the wide disparity between the two series with respect to the percentage distribution of live and stillborn cases in Table VIA. This is in marked contrast to the almost identical distributions of spina bifida cases in the two series. However, it is reasonable to assume that inclusion of stillbirths of 20-27 weeks gestation in the British Columbia data would have increased the percentage of stillbirths among spina bifida cases.

As in other studies the female incidence rate for spina bifida was significantly higher than the male rate in both the British Columbia and the Upper New York studies, as shown in Table VIB. The

TABLE VIA

RECENT RECORDS OF SPINA BIFIDA AND HYDROCEPHALUS Among Live and Stillbirths in Upper New York State and British Columbia

\begin{tabular}{|c|c|c|c|c|c|c|c|c|c|}
\hline & & \multicolumn{4}{|c|}{$\begin{array}{l}\text { Upper New York State (1945-59 } \\
\text { Cohort of 2,552,910 births, including } \\
\text { stillbirths of } 20 \text { weeks or more } \\
\text { gestation) }\end{array}$} & \multicolumn{4}{|c|}{$\begin{array}{c}\text { British Columbia (1952-57 } \\
\text { Cohort of 205,981 births, including 2,339 } \\
\text { stillbirths of } 28 \text { weeks or more } \\
\text { gestation) }\end{array}$} \\
\hline \multirow{2}{*}{\multicolumn{2}{|c|}{ Type of Birth }} & \multicolumn{2}{|c|}{ Spina bifida } & \multicolumn{2}{|c|}{ Hydrocephalus } & \multicolumn{2}{|c|}{ Spina bifida } & \multicolumn{2}{|c|}{ Hydrocephalus } \\
\hline & & $\begin{array}{l}\text { No. of } \\
\text { Cases* }\end{array}$ & Per cent. & $\begin{array}{l}\text { No. of } \\
\text { Cases* }\end{array}$ & Per cent. & $\begin{array}{l}\text { No. of } \\
\text { Casest }\end{array}$ & Per cent. & $\begin{array}{l}\text { No. of } \\
\text { Casest }\end{array}$ & Per cent. \\
\hline \multicolumn{2}{|l|}{ Live } & 2,558 & $84 \cdot 7$ & 886 & $41 \cdot 5$ & 199 & $85 \cdot 0$ & 163 & $70 \cdot 9$ \\
\hline \multicolumn{2}{|l|}{ Still } & 463 & $15 \cdot 3$ & 1,251 & $58 \cdot 5$ & 35 & $15 \cdot 0$ & 67 & $29 \cdot 1$ \\
\hline \multicolumn{2}{|l|}{ Live and Still } & 3,021 & 100 & 2,137 & 100 & 234 & 100 & 230 & 100 \\
\hline $\begin{array}{l}\text { Rate per } 1,000 \\
\text { Total Live and } \\
\text { Stillbirths }\end{array}$ & $\begin{array}{l}\text { Live born cases } \\
\text { Stillborn cases } \\
\text { Live and Stillborn Cases }\end{array}$ & \multicolumn{2}{|c|}{$\begin{array}{l}1 \cdot 00 \\
0 \cdot 18 \\
1 \cdot 18\end{array}$} & \multicolumn{2}{|c|}{$\begin{array}{l}0.35 \\
0.49 \\
0.84\end{array}$} & \multicolumn{2}{|c|}{$\begin{array}{l}0.97 \\
0 \cdot 17 \\
1 \cdot 14\end{array}$} & \multicolumn{2}{|c|}{$\begin{array}{l}0.79 \\
0.33 \\
1 \cdot 12\end{array}$} \\
\hline
\end{tabular}

* From birth records and death records of children under 5 years old.

t From live and dead Registry caseload at the end of 1964 and stillbirth records.

TABLE VIB

ESTIMATES OF SEX-SPECIFIC INCIDENCE RATES OF SPINA BIFIDA AND HYDROCEPHALUS Upper New York State and British Columbia Data

\begin{tabular}{|c|c|c|c|c|c|c|c|c|}
\hline \multirow{3}{*}{ Malformation } & \multicolumn{4}{|c|}{ Upper New York State } & \multicolumn{4}{|c|}{ British Columbia } \\
\hline & \multicolumn{2}{|c|}{ Number } & \multicolumn{2}{|c|}{ Rate per 1,000 births } & \multicolumn{2}{|c|}{ Number } & \multicolumn{2}{|c|}{ Rate per 1,000 Births } \\
\hline & Male & Female & Male & Female & Male & Female & Male & Female \\
\hline Spina bifida & 1,304 & 1,709 & 0.99 & $1 \cdot 38$ & 104 & 130 & 0.99 & $1 \cdot 29$ \\
\hline Hydrocephalus & 1,166 & 965 & 0.89 & $0 \cdot 78$ & 127 & 103 & $1 \cdot 20$ & $1 \cdot 02$ \\
\hline Total Number of Births & $1,311 \cdot 0^{*}$ & $1,242 \cdot 0^{*}$ & & & 105,420 & 100,561 & & \\
\hline
\end{tabular}

\footnotetext{
Approximate, in thousands.
} 
female to male ratio was $1 \cdot 39: 1$ in the Upper New York data and 1.30:1 in the British Columbia data. In the case of hydrocephalus, the male rate was higher in both series, although the difference was not statistically significant in the British Columbia data. However, when Gittelsohn and Milham (1962) separated the Upper New York population into white and non-white components, the latter comprising only 4 per cent. of the total number of births, the male rate for hydrocephalus was found to be higher in the white race but lower among non-whites. The higher female incidence of spina bifida, on the other hand, held true for both races.

\section{Further Augmentation of Registry Data by VITAL RECORDS}

As a result of the growing importance of the Registry as an information centre, a new recording system within the Registry organization was introduced in 1965 further to facilitate access to vital records and to ensure more comprehensive recording. By special arrangement with the central office of the Division of Vital Statistics, the Registry receives copies of live and stillborn records and death records relating to children under 7 years of age in which a congenital defect is mentioned. Information thus obtained is filed under a separate system after a careful check for duplication with the regular Registry caseload. The classification of defects and the organization of the data for research purposes are carefully supervised by two medical consultants and a genetic consultant to the Registry.

As a result of the broader basis of information which has thus been made possible, a more comprehensive programme of studying congenital defects has been undertaken. This involves the use of an expanded coding system, including aetiological and genetic sections, and will be the subject of a future communication.

\section{SUMmaRY}

The use of a central registry for the handicapped in British Columbia for estimating the incidence of congenital defects is described. Although the Registry is a voluntary one, the large number of cases accumulated since its inception in 1952 has made it an important centre of information.

The main advantages of the Registry are:

(1) Access to live birth records as a more or less direct source of registration of defects through its close working relationship with the Division of Vital Statistics.

(2) A vast network of reporting agencies throughout British Columbia through which many cases missed at birth are susequently registered.

The augmentation of the former source of information by the latter is described with examples, con- $\vec{F}$ genital heart disease furnishing the most striking example.

The relative importance of the Registry and of different kinds of vital records for ascertainment $\vec{\nabla}$ in relation to different types of defect is discussed.

For gross malformations with relatively low peri- के natal mortality rates, the Registry has been used as $\overrightarrow{0}$ an exclusive source of information. Estimates of the incidence of the cleft lip and palate complex based exclusively on Registry data are in good agreement with other published estimates.

For congenital defects of a more occult nature and with high post-natal mortality rates, Registry $N$ data must be supplemented by death records. $\stackrel{\rho}{\rightarrow}$ Estimation of the incidence of congenital heart disease based on Registry data thus supplemented is more reliable than estimation based exclusively on birth and death records.

For severe defects with a high stillbirth rate, Registry data must be supplemented by stillbirth records. The use of the Registry in this manner fof ascertaining the incidence of spina bifida and hydro. cephalus is described.

I particularly wish to thank Dr J. R. Miller, Genetic Consultant to the Registry for Handicapped Children and Adults, British Columbia, for his invaluable help $\overrightarrow{\overrightarrow{0}}$ and criticism. I am also grateful to the following persons 3 for their co-operation and advice in the compilation and $\bar{P}$ organization of the data: Messrs J. H. Doughty (Director), W. D. Burrowes, L. W. Hole, and J. F. Rowe of the Division of Vital Statistics, British Columbia; Miss A. E. Scott (Administrator) and Miss E. Houghton of the above mentioned Registry.

\section{REFERENCES}

Fogh-Anderson, P. (1961). Acta chir. scand., 122, 106 (Incidence of cleft lip and palate: constant or increasing?).

Gittelsohn, A. M., and Milham, S. (1962). Brit. J. prev. soc. Med., 16, 153 (Declining incidence of central nervous system anomalies in New York State).

Greene, J. C. (1963). Publ. Hlth Rep. (Wash.), 78, 589 (Epidemiology of congenital clefts of the lip and $\mathrm{N}$
palate).

Gylling, U., and Soivio, A. I. (1962). Acta chir. scand., 123, 0 1 (Frequency, morphology, and operative mortality in cleft lip and palate in Finland).

Henderson, F. M. (1940). J. Speech Hearing Dis., 5, 285 (The incidence of cleft palate in Hawaii).

Ivy, R. H. (1957). Plast. reconstr. Surg., 20, 400 (Congenital anomalies as recorded on birth certificates in the Division of Vital Statistics of the Pennsylvania Department of Health, 1951-1955). 
Loretz, W., Westmoreland, W. W., and Richards, L. F. (1961). Amer. J. Publ. Hlth, 51, 873 (A study of cleft lip and cleft palate births in California), 1955.

MacMahon, B., and McKeown, T. (1953). Amer. J. hum. Genet., 5, 176 (The incidence of harelip and cleft palate related to birth rank and maternal age).

Milham, S. (1963). Amer. J. Dis. Child., 106, 185 (Underreporting of incidence of cleft lip and palate).

Miller, J. R. (1964). In "Second International Conference on Congenital Malformations, New York, 1963", pp. 334-340. International Medical Congress Ltd., New York. (The use of registries and vital statistics in the study of congenital malformations.)

Mott, G. A. (1963). Canad. J. Publ. Hlth, 54, 239 (The registry of handicapped children and adults in British Columbia).

Neel, J. V. (1958). Amer. J. hum. Genet., 10, 398 (A study of major congenital defects in Japanese infants).
Newcombe, H. B. (1966). Brit. J. prev. soc. Med., 20, 49 (Familial tendencies in diseases of children).

Osterud, H. T., Menashe, V. D., and Martin, M. M. (1965). Publ. Hlth Rep. (Wash.), 80, 721 (Use of vital records in the study of congenital heart disease).

Pleydell, M. J. (1960 . Brit. med. J., 1, 309 (Anencephaly and other congenital abnormalities: An epidemiological study in Northamptonshire).

Rank, B. K., and Thomson, J. A. (1960). Med. J. Aust., 47 (2), 681 (Cleft lip and palate in Tasmania).

Renwick, D. H. G., Miller, J. R., and Paterson, D. (1964). Canad. med. Ass. J., 91, 365 (Estimates of incidence and prevalence of mongolism and of congenital heart disease in British Columbia).

Wallace, H. M., Hoenig, L., and Rich, H. (1956). Amer.J. Dis. Child., 91, 529 (Newborn infants with congenital malformations or birth injuries). 